\title{
ПРОЦЕССЫ ЭЛЕКТРОСТАТИЧЕСКОЙ СЕПАРАЦИИ И ФЛОТАЦИИ В ОБОГАЩЕНИИ ИЛЬМЕНИТОВЫХ РУД ИЗ ВЬЕТНАМА И ХИМИЧЕСКАЯ ПЕРЕРАБОТКА ПОЛУЧЕННЫХ КОНЦЕНТРАТОВ
}

\author{
Карелин Владимир Александрович1, \\ vakarelin@tpu.ru
}

\author{
Ле Хай Шон², \\ son.hut2006@gmail.com
}

Карелина Надежда Владимировна',
nvkarelina@yandex.ru

\section{Ле Хуонг Тхи Май³,} huonghvc@gmail.com

1 Национальный исследовательский Томский политехнический университет, Россия, 634050, г. Томск, пр. Ленина, 30.

2 Технологический институт радиоактивных и редкоземельных элементов, Вьетнамский институт по Атомной энергии, Вьетнам, 11513, г. Ханой, ул. Ланг Ха, 48, Донг Да.

з Высший университет науки и технологий Вьетнамской академии науки и технологий, Вьетнам, 11518, г. Ханой, ул. Хоанг Куок Вьет, район Кау Гиэй.

\begin{abstract}
Актуальность исследования определяется созданием принципиально нового способа синтеза титановых порошков высокой степени чистоты из ильменитовых руд месторождений Вьетнама, содержащих в тяжелой фракции смесь ильменита с рутилом. Это одно из приоритетных направлений комплексного развития месторождений редких и редкоземельных элементов во Вьетнаме.

Цель: выбор условий, методов и последовательности проведения технологических операций по обогащению вьетнамских ильменитовых руд и последующей их химической переработки с получением высокочистого титана.

Объекты: ильменитовая руда месторождения Ха Тинь (Вьетнам) с высоким содержанием оксидов титана, железа, циркония и низким содержанием кремния, алюминия, редкоземельных элементов, ванадия, а также ильменитовый концентрат, полученный в результате обогащения исходной ильменитовой руды.

Методы: в процессе обогащения - электростатическая сепарация, фрлотация, использование коллекторов, активаторов и депрессоров, добавляемых к флотореагентам; при электролитическом синтезе титана - применение расплава в виде смеси фтторидов лития, натрия и калия, обладающих минимальной температурой плавления, с добавкой тетрафторида титана; выбор условий запуска электролизера, катодной плотности тока, силы тока и напряжения для осаждения титана на катоде; исследование оптимальных условий выделения титанового порошка при низких температурах с использованием безводного фртороводорода.

Результаты. Показана перспективность использования методов электростатической сепарации и фрлотации при обогащении вьетнамских ильменитовых руд месторождения Ха Тинь. Получен ильменитовый концентрат с содержанием диоксида титана более 50 \%. Обоснованы преимущества использования метода прямого фрторирования ильменитового концентрата элементным фттором, позволяющего обеспечить полноту его вскрытия и отделить летучие фрториды титана, ниобия, ванадия и кремния от нелетучих - фторидов железа, циркония, гафрния и церия. Это позволяет оптимизировать число стадий при дальнейшем применении $\mathrm{TiF}_{4}$ в качестве материала для получения титанового порошка. При электролитическом получении титана обоснована необходимость применения расплава фоторидных солей лития, натрия и калия, имеющих состав: LiF (0,465 M)-NaF (0,115 M)-KF (0,42 M), обладающего минимальной температурой плавления $\left(454^{\circ} \mathrm{C}\right)$ и пределами изменения концентрации $\mathrm{K}_{2} \mathrm{TiF}_{6}(25-30$ \%). При этом величины плотности тока и выхода по току приближаются к максимальным значениям - 3,5-4,0 A/см² и 60-65 \% соответственно. Содержание примесей в титановом порошке не превышает 0,135\%, что удовлетворяет требованиям для изготовления изделий из компактного титана.
\end{abstract}

\section{Ключевые слова:}

Ильменитовая руда и концентрат из Вьетнама, обогащение методами электростатической сепарации и флотации, электролиз в низкоплавкой эвтектике фторидов щелочных металлов и титана, гранулометрический и химический составы титанового порошка.

\section{Введение}

В новейшей истории все большее значение приобретают материалы и изделия, предназначенные для работы в условиях повышенных механических нагрузок, давлений и температур (в так называемых «жестких» условиях). Наиболее часто используемый в этих условиях материал - титан и его сплавы, поэтому возникает необходимость в создании технологии получения таких материалов высокой чистоты, удовлетворяющих вышеописанным требованиям. Сейчас единственной промышленной технологией получения титана является Кролл-процесс [1], основные недостатки которой - низкая производительность, большое количество токсичных выбросов и необходи- 
мость использования магния на финишной стадии процесса.

Одним из ключевых процессов титановой технологии является обогащение основных титановых руд - ильменита и рутила. Вьетнам является крупнейшим производителем титановых руд в мире. Объем их производства превышает $8 \%$ (пятое место). Обогащение ильменитовых руд во Вьетнаме обычно проводят гравитационными методами (на концентрационных столах) [2, 3], а для дальнейшего увеличения содержания ильменита в концентрате применяют методы магнитной сепарации $[4,5]$.

Однако такая технология обогащения не обладает высокой эффективностью, хотя и позволяет получать концентраты с высоким содержанием $\mathrm{TiO}_{2}$ [6-8]. Поэтому для создания конкурентоспособной технологии и проведения процесса обогащения необходимо использовать более современные методы [9-11]. В настоящей работе авторами проведены исследования по изучению процессов обогащения вьетнамских ильменитовых руд методами электростатической сепарации и флотации.

Не менее важна химическая переработка полученных титановых концентратов. Для производства чистого порошка гидрида титана в качестве модификации Кролл-процесса был разработан АДМА-процесс [12]. Ключевым этапом этого процесса является введение газообразного водорода в реактор на каждой стадии процесса, включая восстановление, разделение фаз и охлаждение. Для снижения стоимости титанового порошка проведены исследования по разработке нескольких альтернативных процессов для того, чтобы Кролл-процесс сделать непрерывным, например TiRO-процесс, разработанный CSIRO [13], процесс восстановления в паровой фазе, разработанный Д. Хансеном и др. [14], и процесс CSIR-Ti, разработанный Д. Вууреном и др. [15]. B MHR-процессе для получения металлического Ті при восстановлении $\mathrm{TiO}_{2}$ используют Са. В качестве восстановителей исследованы четыре различные формы $\mathrm{Ca}$ г гидрид $\mathrm{CaH}_{2}$, пары Са и жидкий $\mathrm{Ca}[16]$.

В настоящее время разработано несколько современных процессов, позволяющих получать металлический титан. Наиболее известные из них FFC (Cambridge)-процесс [17], восстановление предварительно спеченной заготовки-брикета (PRP-процесс) [18], электролиз с использованием Ті-содержащего материала в качестве анода (USTB-процесс) [19], OSпроцесс (Osaka-process) [20]. В последние несколько лет широкое распространение получил процесс электрорафинирования оксикарбидов (Chinuka-процесс) [21]. Однако во всех перечисленных процессах в качестве исходного материала используется предварительно очищенный диоксид титана, и от его чистоты (содержания примесей) зависит качество синтезируемого металлического титана.

В этой статье авторами предложен процесс прямого фторирования вьетнамских ильменитовых концентратов элементным фтором с последующим электролитическим восстановлением образовавшегося тетрафторида титана в расплаве фторидных солей ще- лочных металлов - лития, натрия и калия. Такая технология позволить отказаться от использования вспомогательных веществ (например, магния в Кролл-процессе), улучшить экологическую ситуацию как на предприятии, так и вокруг него за счет резкого уменьшения токсичных выбросов. Производительность завода, использующего предложенную технологию, может варьироваться в широких пределах.

\section{Материалы и методы}

Выполнены исследования по обогащению и последующей химической переработке ильменитовых руд месторождения Ха Тинь (Вьетнам). Состав исходной ильменитовой руды $\%: \mathrm{TiO}_{2}-41,10$; $\mathrm{FeO}+\mathrm{Fe}_{2} \mathrm{O}_{3}-25,89 ; \mathrm{ZrO}_{2}-12,48 ; \mathrm{SiO}_{2}-9,69 ; \mathrm{Al}_{2} \mathrm{O}_{3}-$ 4,67; $\mathrm{CeO}_{2}-0,22 ; \mathrm{HfO}_{2}-0,20 ; \mathrm{Nb}_{2} \mathrm{O}_{5}-0,16 ; \mathrm{V}_{2} \mathrm{O}_{5}-$ 0,08 . Общее содержание основных компонентов достигает 94,5\%, содержание микропримесей не превышает 5,5\%.

Обогащение ильменитовых руд проводили методами электростатической сепарации и флотации. Выбор этих методов определяется тем, что при использовании электростатического метода происходит отделение титановых минералов (рутила и ильменита) от пустой породы. Флотационный метод позволяет увеличить концентрацию титановых минералов в обогащенном продукте и в дальнейшем использовать его для последующей химической переработки. В результате фторирования полученного ильменитового концентрата образуется $\mathrm{TiF}_{4}$, из которого методами электролитического восстановления синтезировали титановый порошок.

\section{Экспериментальные установки}

При проведении исследований с использованием метода электростатической сепарации использовали электростатический сепаратор ЭЛКОР-1 с изменяющейся полярностью высоковольтных электродов. Диаметр и длина осадительного электрода (барабана) 240 и 250 мм соответственно, скорость его вращения 55-370 об/мин.

Флотационный процесс проводили с помощью флотационной машины ФМФ-3(л), в которой предварительно подготовленная исходная пульпа поступает в камеру флотационной машины. По вертикальному трубопроводу, совмещенному с валом импеллера, в нижнюю часть эжектируется воздух, обеспечивающий перемешивание пульпы и образование пены. Пенная фракция (концентрат) отводится из верхней части, а камерный продукт (пульпа) - из нижней части флотационной машины. Вместимость камеры 3 л, диаметр импеллера 55 мм.

Для проведения флотации ильменитовых руд в качестве коллектора использовали олеат натрия (натриевую соль олеиновой кислоты, $\mathrm{NaOl}$ ). Перед флотацией взвешивали пробу исходной руды массой 100 г и 1-2 г NaOl. Эту смесь перемешивали в течение 3 минут. Воду для флотации очищали на установке методом обратного осмоса. Во флотационную машину наливали 1 л воды с температурой $22-25^{\circ} \mathrm{C}$ и добавляли подготовленную пробу. После перемешива- 
ния полученной смеси в течение 3-5 мин во флотационную машину добавляли еще 2 л воды так, чтобы общий ее объем составил 3 л. Флотацию проводили при барботировании воздуха с помощью эжектирующего блока импеллера. В процессе вспенивания частицы руды переходят в пену, которую собирали в верхней части аппарата и с помощью специальных лопаток удаляли в сборную емкость. По окончании процесса флотации получали отдельно пенный и камерный продукты, из которых фильтрованием выделяли твердую фазу, высушивали и взвешивали [22].

В результате обогащения руд месторождения Ха Тинь (Вьетнам) получен ильменитовый концентрат, состав которого приведен в табл. 1.

Таблица 1. Состав основных компонентов ильменитового концентрата месторождения Ха Тинь (Вьетнам)

Table 1. Composition of the main components of ilmenite concentrate from the Ha Tinh deposit (Vietnam)

\begin{tabular}{|l|c|c|c|c|c|c|c|c|c|c|c|}
\hline $\begin{array}{l}\text { Компонент } \\
\text { Component }\end{array}$ & $\mathrm{TiO}_{2}$ & $\mathrm{FeO}$ & $\mathrm{Fe}_{2} \mathrm{O}_{3}$ & $\mathrm{MnO}$ & $\mathrm{SiO}_{2}$ & $\mathrm{CaO}$ & $\mathrm{MgO}$ & $\mathrm{Al}_{2} \mathrm{O}_{3}$ & $\mathrm{~V}_{2} \mathrm{O}_{5}$ & $\mathrm{Cr}_{2} \mathrm{O}_{3}$ & $\mathrm{Bcerо}$ \\
\hline $\begin{array}{l}\text { Coдержание, \% мас. } \\
\text { Content, \% wt. }\end{array}$ & 51,74 & 23,31 & 16,73 & 3,35 & 2,48 & 0,06 & 0,23 & 1,02 & 0,14 & 0,05 & $99,11 *$ \\
\hline
\end{tabular}

*Остальное - микропримеси.

*Microimpurities compose the rest of the content.

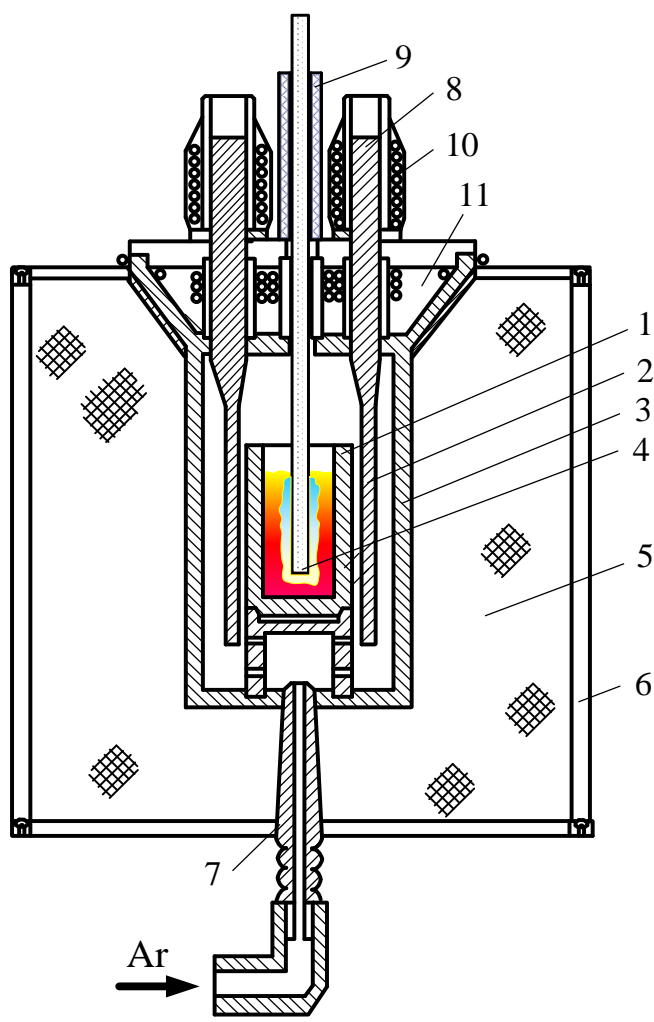

Puc. 1. Схема электролизера для синтеза титана: 1 графитовый тигель (подключен к положительному полюсу источника питания); 2 - нагреватель из углеродсодержащего материала (состоит из 2-х частей); 3 - камера из углеродсодержащего материала; 4 - катод; 5 - теплоизоляция - порошок графита; 6 - металлический корпус; 7 - штуцер для подачи инертного газа (Ar); 8 - углеродные стержни для разогревания тигля; 9 - уплотнение катода из фторопласта; 10 - водяное охлаждение; 11 - головка электролизера - графит

Fig. 1. Diagram of an electrolytic cell for titanium synthesis. 1 - graphite crucible - anode; 2 - split graphite heater; 3 - graphite cell of the electrolyzer; 4 cathode; 5 - thermal insulation - graphite powder; 6 - steel casing; 7 - inlet of argon; 8 - heater contact device; 9 - stuffing box seal of the cathode; $10-$ water cooling; 11 -electrolyzer head-graphite
Концентрат указанного состава фторировали элементным фтором на специальной установке [23]. $\mathrm{B}$ результате фторирования получали $\mathrm{TiF}_{4}$, который направляли на электролитическое извлечение титанового порошка в расплаве фторидных солей щелочных металлов.

Электролиз проводили в аппарате, схема которого изображена на рис. 1. Нагреватель -2 и внутренние части электролизера выполнены из углеродсодержащего материала и находятся в металлическом защитном корпусе - 5. Для обеспечения низкой теплоотдачи внутрь металлического корпуса помещали тонкий графитовый порошок (мелкодисперсный углерод) - 4 . В объем тигля из углерода - 1 засыпали исходные фторидные соли ( $\mathrm{LiF}, \mathrm{NaF}$ и $\mathrm{KF} \cdot \mathrm{HF})$, которые при нагревании расплавлялись с образованием однородного расплава электролита (эвтектической смеси фторидных солей). HF использовали для уменьшения температур плавления $\mathrm{LiF}$ и $\mathrm{NaF}$ за счет образования их соответствующих гидрофторидов. На заключительной стадии расплав нагревали до $\sim 600{ }^{\circ} \mathrm{C}$ и удаляли HF. В ходе процесса углеродный тигель подключали к положительному полюсу источника питания. Тигель рассчитан на загрузку 3 кг электролита [24].

Основной недостаток такого электролизера состоит в том, что графитовые тигли пропускают расплав, поэтому в них невозможно длительное время проводить электролиз и после замены катода 5-6 раз процесс останавливали и графитовый тигель заменяли. Для устранения этого недостатка необходимо изменить конструкцию электролизера. Наиболее перспективной конструкцией является электролизер со слоем гарниссажа (рис. 2). Корпус аппарата выполнен в виде параллелепипеда из стальных листов с рубашкой охлаждения, через которую прокачивается вода. В вертикальной части корпуса расположены отверстия для электродов из графита, подключенных к положительному полюсу источника питания постоянного тока. Для нагревания расплава в режимах электролиза, запуска электролизера и поддержания необходимой температуры предназначены два нагревателя, на которые подается переменный ток. 


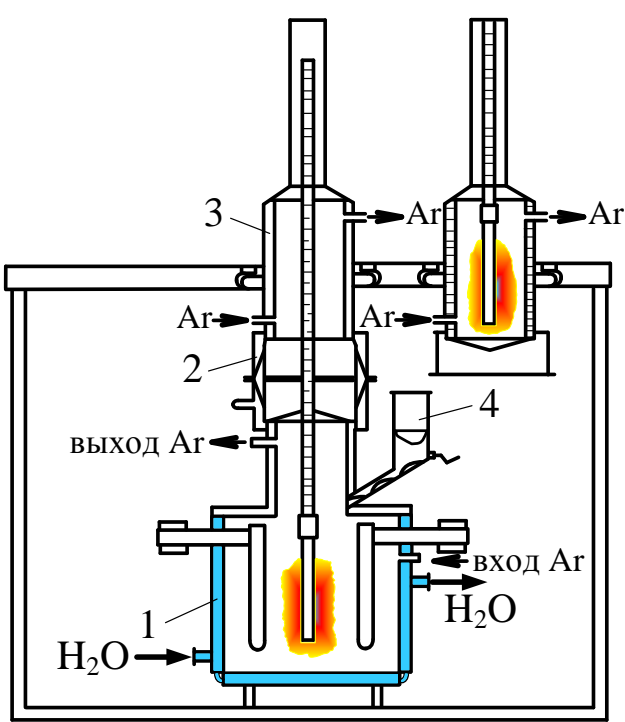

Pис. 2. Электролизер со слоем гарниссажа: 1 - стальной охлаждаемыий водой корпус со слоем гарниссажа; 2 - разъемный шлюз; 3 - охладительная камера; 4 - бункер

Fig. 2. Electrolyzer with a layer of skull: 1 - steel watercooled body with a layer of skull; 2 - detachable gateway; 3 - cooling chamber; 4 - bunker

Расплав электролита, соприкасаясь со стенками электролизера, затвердевает на них в виде корки (гарниссажа), предохраняющей стенки электролизера - 1 от коррозионного воздействия перешедших в жидкость фторидных солей. Образующийся на анодах элементный фтор отводится из верхней части электролизера. Образующаяся на аноде газовая фаза удаляется через специальное устройство, расположенное в верхней части электролизера. В шлюзовой камере - 2 имеются отсечные вентили для предотвращения попадания воздуха в охладительную камеру - 3 и электролизер при снятии охладительной камеры.

В конструкции электролизера предусмотрено специальное устройство, позволяющее переместить ка-

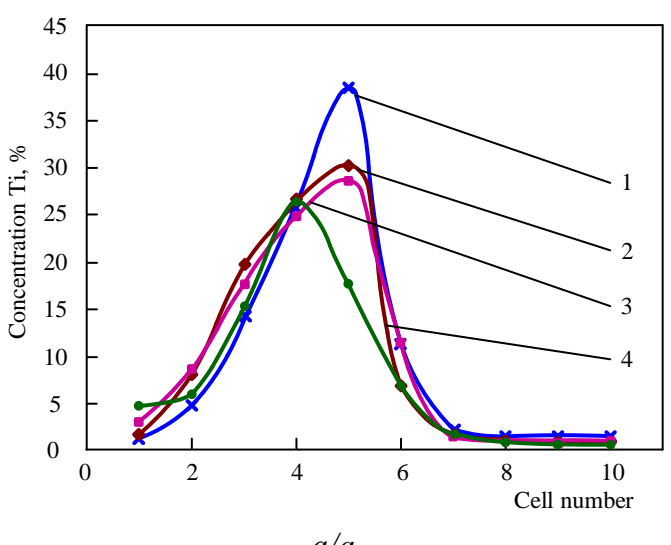

$a / a$ тод с выделившимся осадком в герметичную камеру, с последующей продувкой инертным газом (аргоном) для удаления остатков выделившегося в процессе элементного фтора. Для герметизации держателя катода используют гофрированную резиновую трубку. На нижнем конце держателя расположен катод, изготовленный из инертного во фторидных средах материала, например никеля. Замену никелевого стержня, подачу фторидных солей и удаление использованного электролита проводят в среде инертного газа. При этом обеспечиваются условия, не приводящие к нарушению герметичности емкости с образовавшимся осадком. В этих условиях осадок находится в течение нескольких часов, а затем его отмывают от солей электролита.

\section{Результаты и обсуждение \\ Применение электростатической сепарации для обогащения ильменитовых руд}

При обогащении ильменитовых руд установлено, что при увеличении напряжения между электродами сепаратора с 25 до 35 кВ изменяется распределение основных компонентов титановых минералов (титана и железа) в 10-ти ячейках сепаратора (рис. 3). Показано, что Ті и Fе распределяются в ячейках с 1 по 5 в зависимости от приложенного напряжения. Распределение этих компонентов не изменяется при 30 кВ и более. Поэтому для обеспечения эффективности разделения напряжение, подаваемое на электростатический сепаратор, должно быть не менее 30 кВ.

Поведение основных примесей ильменитового концентрата - кремния, циркония и алюминия - в процессе обогащения методом электростатической сепарации показано на рис. 4. С увеличением напряжения между электродами сепаратора с 25 до 35 кВ область выделения оксидов кремния и циркония (рис. $4, a, \sigma)$ смещается от 4-6 ячеек к 8-10 ячейкам. Это позволяет отделить эти оксиды от ильменита и рутила.

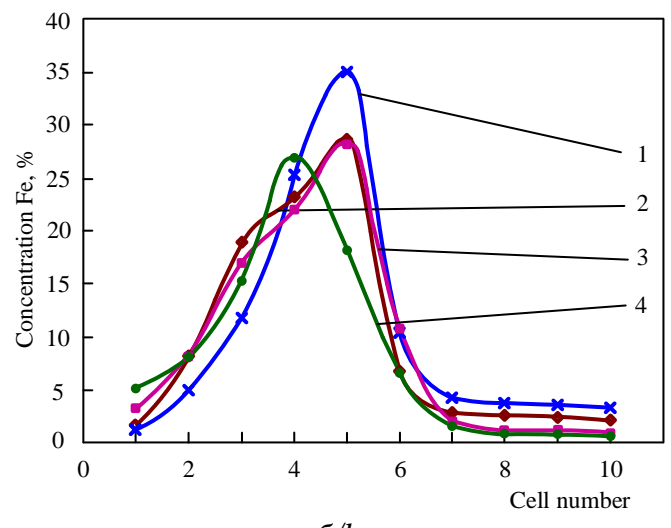

$\sigma / b$

Pис. 3. Зависимость изменения содержания титана (а) и железа (б) в полученных фракциях в ячейках сепаратора от напряжения на электродах. Напряжение между электродами сепаратора (кB): 1 - 25; 2 - 27,5; 3 - 30; $4-35$

Fig. 3. Dependence of change of titanium $(a)$ and iron $(b)$ content in the obtained fractions in the separator cells on the voltage at the electrodes. Voltage between separator electrodes $(k V): 1-25 ; 2-27,5 ; 3-30 ; 4-35$ 
Отделить оксид алюминия от целевых титановых минералов гораздо сложнее. При увеличении напряжения между электродами сепаратора с 25 до 30 кВ $\mathrm{Al}_{2} \mathrm{O}_{3}$ по-прежнему выделяется вместе с основными минералами в 4-6 ячейках сепаратора. Только при увеличении напряжения до 35 кВ пик выделения $\mathrm{Al}_{2} \mathrm{O}_{3}$ смещается к 8-10 ячейкам (рис. 4, в).

Таким образом с учетом поведения основных компонентов примесей титановых минералов для их отделения от ильменита и рутила необходимо поддерживать напряжение между электродами сепаратора не менее 35 кВ.

Дальнейшее увеличение концентрации титана в целевой фракции необходимо проводить методом электромагнитной сепарации. Отделение ильменита и рутила в обогащенном продукте необходимо проводить методом электромагнитной сепарации, позволя-

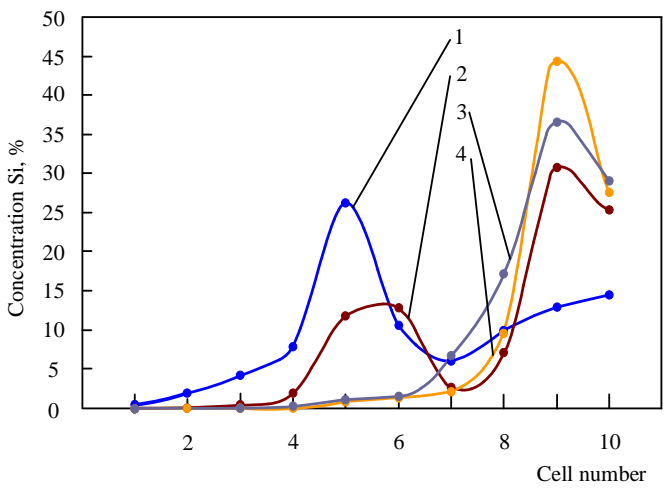

$a / a$

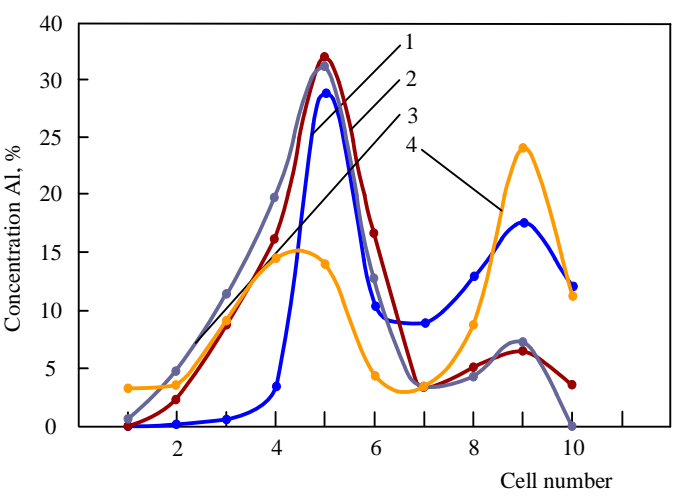

b/c

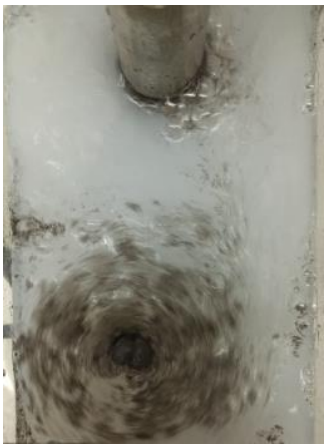

$a / a$

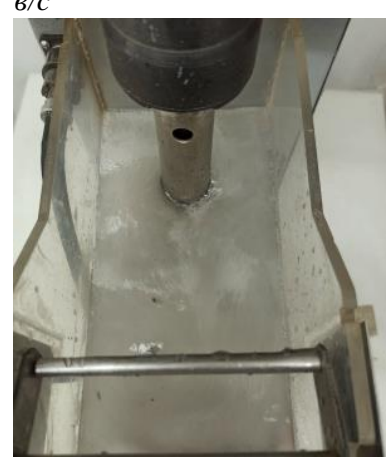

$\sigma / b$

ющим отделить обладающий магнетизмом ильменит от немагнитного рутила.

\section{Флотация в процессах обогащения ильменита}

Выбор оптимального времени фрлотации

Время - ключевой параметр процесса флотации. Определив его, можно рассчитать размеры как лабораторной, так и промышленной флотационной машины.

На рис. 5 показаны основные стадии флотации: перемешивание пробы в воде, начало процесса, образование пены и удаление пенного продукта. Для определения времени процесса флотации и выбора оптимального его значения через $1,3,5,8$ 10, 12 и 15 минут отбирали пробы пенного продукта и определяли в них количество твердого компонента и концентрации титана и железа.

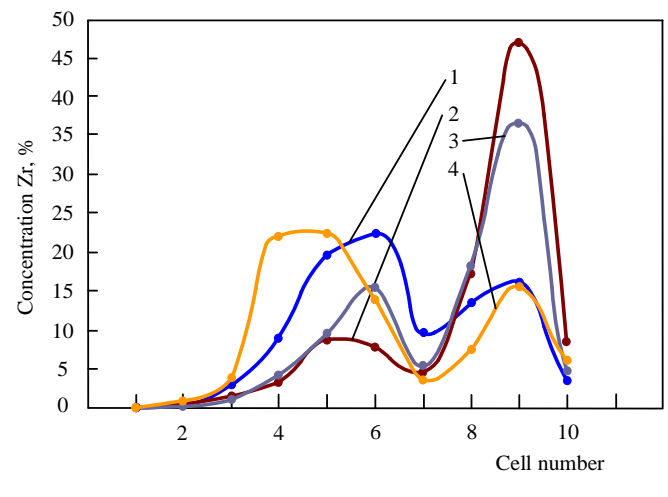

$\sigma / b$

Pис. 4. Зависимость изменения содержания кремния (а), циркония (б) и алюминия (в) в полученных фракциях в ячейках сепаратора от напряжения на электродах. Напряжение между электродами сепаратора $(\kappa B): 1-25 ; 2-27,5 ; 3-30$ $4-35$

Fig. 4. Dependence of change of silicon (a), zirconium (b) and aluminum (c) content in the obtained fractions in the separator cells on the voltage at the electrodes. Voltage between separator electrodes $(k V)$ : $1-25 ; 2-27,5 ; 3-30 ; 4-35$

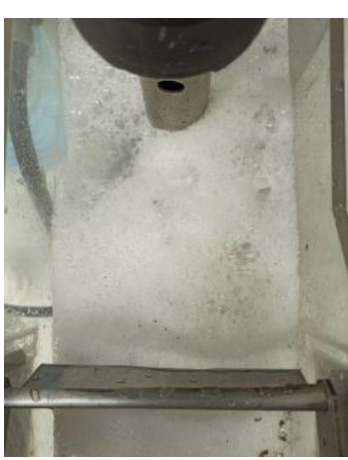

b/c

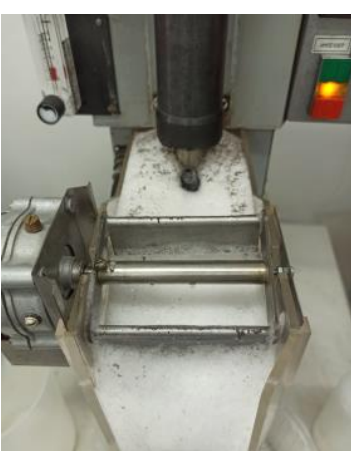

$2 / d$

Pис. 5. Основные стадии процесса флотации: а) перемешивание пробы в воде; б) начало процесса; в) образование пены; г) удаление пенного продукта 
Fig. 5. Main stages of flotation: a) mixing the sample in water; b) beginning of the process; c) foam formation; d) foam product removal

Изменение концентрации и степени обогащения титана (ๆ) в пенный продукт от времени флотации представлены на рис. 6. Показано, что основная флотация протекает за 8 минут. Концентрация $\mathrm{TiO}_{2}$ в пенной фракции возрастает с 30,45 до 37,13 \%. Необходимо отметить, что количество полученного продукта со временем уменьшается.

Наибольшая степень обогащения, равная 84 \%, достигается в течение 10 минут флотации. Однако концентрация титана в продукте постепенно снижается из-за попадания в него большого количества примесей. Таким образом, оптимальное время флотации изменяется в пределах от 5 до 10 мин, а наилучшие показатели достигаются через 8 мин после начала процесса.

\section{Влияние количества олеата натрия на эффеективность} обогащения ильменита

В процессе флотации олеат натрия $(\mathrm{NaOl})$ используют в качестве вспенивателя и собирателя для выделения частиц руды в пенную фазу. Концентрация $\mathrm{NaOl}$ является важным параметром, поскольку она влияет на способность к пенообразованию и на время проведения процесса. Если концентрация $\mathrm{NaOl}$ слишком велика, то процесс обогащения протекает быстро, но из-за слишком большого количества пены вместе с целевым компонентам руды в пенном продукте будут присутствовать другие примеси. Это приводит к тому, что степень извлечения продукта будет высокой, а содержание $\mathrm{TiO}_{2}$ в нем - низким. Если концентрация $\mathrm{NaOl}$ слишком мала, то пенообразующая способность снижается, время проведения процесса сокращается, количество полученного пенного продукта уменьшается, что влияет на эффективность процесса. Поэтому концентрация $\mathrm{NaOl}$ является одним из основных параметров флотации.

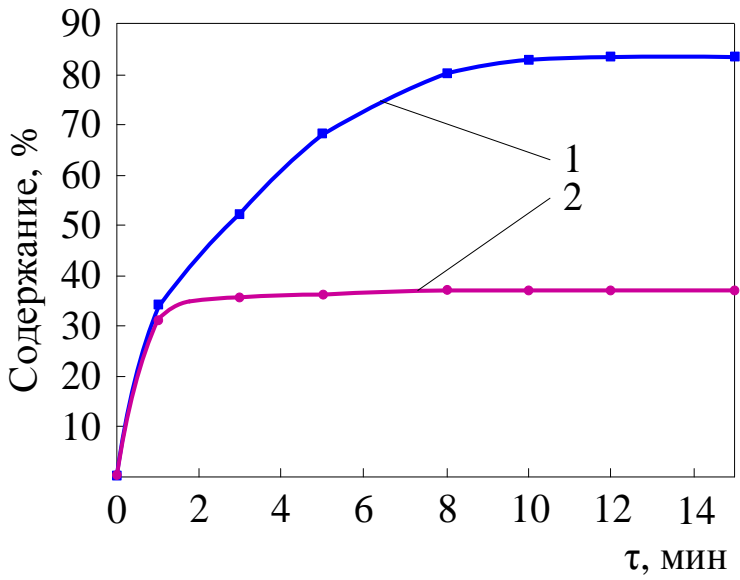

Pис. 6. Влияние времени на эффективность флотации: 1 - концентрация $\mathrm{TiO}_{2}$ в продукте; 2 - степень обогащения титана

Fig. 6. Influence of time on flotation efficiency: $1-\mathrm{TiO}_{2}$ concentration in the product; 2 - benefication degree of titanium
Для проведения исследований использовали 4 образца ильменитовой руды массой по 20 г, в которые добавляли 0,$25 ; 0,5 ; 0,75$ и 1,0 г $\mathrm{NaOl}$. Полученные смеси тщательно перемешивали в течение 3 минут. Затем каждый из образцов (по отдельности) помещали во флотационную машину и смешивали с водой (объем 3 л). При этом $\mathrm{NaOl}$ растворялся в воде с образованием пенной фазы. Концентрация $\mathrm{NaOl}$ в растворах составила 0,$09 ; 0,18 ; 0,27$ и 0,36 г/л соответственно. Исследования проводили при $\mathrm{pH} 7$. Для корректировки кислотности среды использовали растворы $1 \mathrm{M} \mathrm{NaOH}$ и 0,8 $\mathrm{M} \mathrm{H}_{2} \mathrm{SO}_{4}$. На рис. 7 показаны результаты изменения концентрации и степени обогащения титана в пенную фракцию от концентрации $\mathrm{NaOl}$.

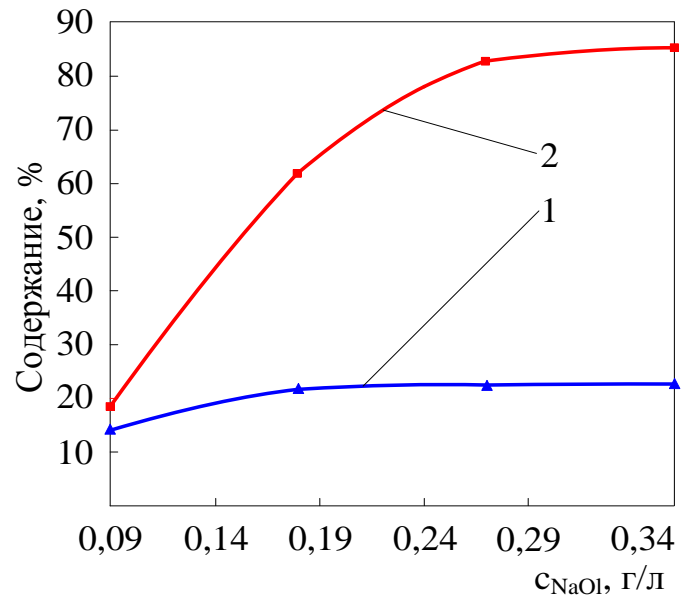

Pис. 7. Влияние концентрации $\mathrm{NaOl}$ на эффективность флотачии: 1 - концентрация $\mathrm{TiO}_{2}$ в продукте; 2 - степень обогащения титана

Fig. 7. Influence of $\mathrm{NaOl}$ concentration on flotation efficiency: $1-\mathrm{TiO}_{2}$ concentration in the product; $2-$ benefication degree of titanium

В растворе $\mathrm{NaOl}$ с концентрацией 0,09 г/л количество пены очень мало. На поверхности водной фазы образуется тонкая пленка пены. Частицы ильменитовой руды, переходящие из водного раствора в пенную пленку, не удерживаются в ней и переходят обратно в водную фазу. Процесс разделения происходит очень медленно. Из-за плохого разделения количество примесей в пенном продукте увеличивается. В него переходит только $24 \%$ твердой фазы от исходного количества, а степень извлечения не превышает $20 \%$.

При концентрации $\mathrm{NaOl}$, равной 0,18 г/л, количество (объем) пенного продукта возрастает. Частицы ильменитовой руды начинают удерживаться слоем пены. В этих условиях время флотации не превышает 3 минут. Степень извлечения продукта через 3 минуты достигла $61 \%$, а содержание твердой фазы в нем составило $\sim 36 \%$.

С увеличением концентрации $\mathrm{NaOl}$ в растворе до 0,27 и 0,36 г/л образуется достаточное для проведения флотации количество пенного продукта, которое 
остается постоянным в течение 10 минут. Скорость образования продукта высокая, степень извлечения титана более 80 \%, а содержание твердой фазы в продукте более $37 \%$.

Количество $\mathrm{NaOl}$, необходимое для проведения флотации, зависит от кислотности рабочей среды. При величине $\mathrm{pH}=2,3,4,5,6,7,8,9$ и 10 выполнены исследования по изучению влияния кислотности среды на количество добавляемого NaOl. На рис. 8 показано, что в нейтральной и щелочной средах (при $\mathrm{pH}=6$-9) для обеспечения высокой скорости образования пены в раствор объемом 3 л достаточно добавить 1 г $\mathrm{NaOl}$, а с увеличением кислотности среды при $\mathrm{pH}=5$ и 4 количество $\mathrm{NaOl}$ возрастает до 2,5 и 3 г соответственно.

Флотация (появление пены) начинается только при $\mathrm{pH}=3$. При $\mathrm{pH}=2$ пена вообще не образуется. Поэтому при увеличении кислотности среды необходимо использовать большее количество $\mathrm{NaOl}$. Чем ниже pH среды (чем выше кислотность), тем большее количество $\mathrm{NaOl}$ необходимо добавлять в раствор.

Таким образом флотация протекает только при концентрации $\mathrm{NaOl}$ не менее 0,27 г/л. Степень обогащения титана может достигать 80 \% при концентрации в пенной фракции $\sim 37 \% \mathrm{TiO}_{2}$. Флотацию ильменитовой руды лучше проводить в слабокислой или нейтральной средах (при $\mathrm{pH}=5-7)$.

\section{Влияние концентрации $\mathrm{TiO}_{2}$ в руде}

на эффрективность фрлотации

На рис. 9, а показано, что эффективность флотации сильно зависит от концентрации титана в исходной руде. Чем больше концентрация титана в руде, тем выше степень извлечения и тем выше концентрация титана в полученном продукте. Это можно объяснить тем, что чем большее количество примесей находится в исходной руде, тем большее влияние они будут оказывать на флотацию ильменита. В то же время эти примеси будут переходить в пенную фазу и всплывать вместе с ильменитом.

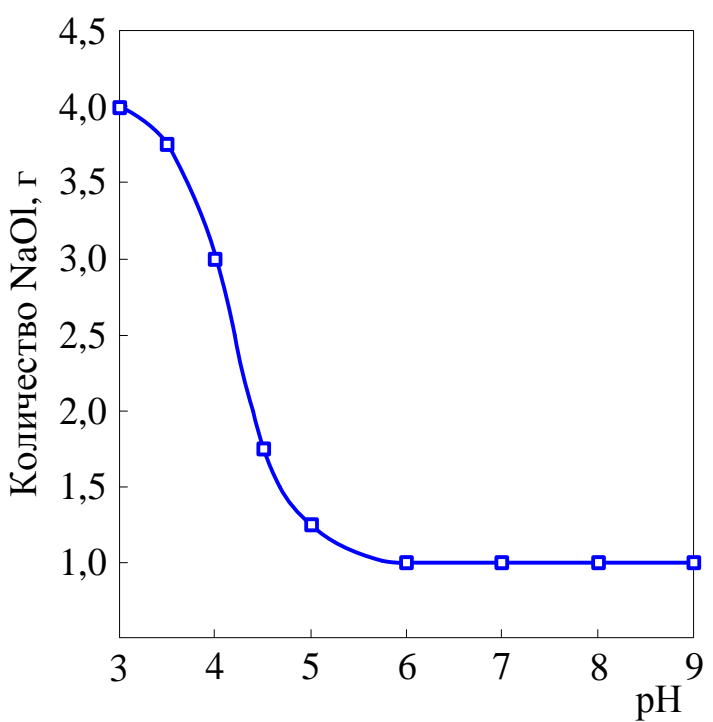

Pис. 8. Влияние кислотности среды на количество $\mathrm{NaOl}$ в проиессе флотации
Fig. 8. Influence of medium acidity on the amount of $\mathrm{NaOl}$ in flotation

Кроме того, показатели процесса флотации ильменита улучшаются при его предварительной обработке. Такую обработку проводят окислителями и восстановителями для изменения заряда поверхности частиц. В результате возрастает реакционная способность коллектора $(\mathrm{NaOl})$ и значительно улучшаются флотационные свойства частиц. В процессе окисления катионов $\mathrm{Fe}^{2+}$, находящихся на поверхности частиц ильменита, кислородом воздуха образуются $\mathrm{Fe}^{3+}$ по реакции: $\mathrm{Fe}^{2+}-\mathrm{e}^{-} \leftrightarrow \mathrm{Fe}^{3+}$. Комплексообразующая способность $\mathrm{Fe}^{3+}$ с коллектором гораздо выше, чем $\mathrm{Fe}^{2+}$, поэтому катионы $\mathrm{Fe}^{3+}$ будут переходить в пенную фазу. Эту особенность можно использовать и для разделения рутила и ильменита флотационным методом. Для этого необходимо провести процесс восстановления катионов $\mathrm{Fe}^{3+}$ в $\mathrm{Fe}^{2+}$. В этих условиях камерный продукт будет обогащаться ильменитом, a пенная фракция - рутилом. Разделение улучшается в среде $\mathrm{H}_{2} \mathrm{SO}_{4}, \mathrm{NaF}$ и $\mathrm{Pb}\left(\mathrm{NO}_{3}\right)_{2}$.

Эффективность флотации возрастает при концентрации $\mathrm{TiO}_{2}$ в руде более $20 \%$ и степени обогащения более $80 \%$. Концентрация $\mathrm{TiO}_{2}$ в обогащенной фракции может достигать 36 \%. На рис. 9, б показаны результаты исследований изменения степени обогащения от концентрации $\mathrm{TiO}_{2}$ в ильменитовой руде. Исследования проведены при $\mathrm{pH}=3,4-7$ в течение 10 минут. Концентрация $\mathrm{NaOl}$ в исходном растворе равна 0,33 г/л.

Показано, что при концентрации титана в руде 25 $\%$ и выше степень обогащения изменяется незначительно и составляет $\sim 86 \%$. При концентрации титана в руде менее $25 \%$ концентрация $\mathrm{TiO}_{2}$ в обогащенной фракции возрастает гораздо быстрее. Например, при концентрации $\mathrm{TiO}_{2}$ в руде менее $40 \%$ концентрация $\mathrm{TiO}_{2}$ в пенной фракции возрастает с 38,91 до 43,60 ( на 5 \%). На рис. 9, 6 показано, что при концентрации $\mathrm{TiO}_{2}$ в исходной руде более $40 \%$ концентрация $\mathrm{TiO}_{2}$ в полученном продукте увеличивалась гораздо медленнее, хотя степень обогащения была высокой и достигла $\sim 86 \%$. Причину этого можно объяснить высокой концентрацией $\mathrm{FeO}$ в руде, при которой ее флотационные свойства недостаточно хорошие. Следовательно, при использовании олеата натрия в качестве коллектора при флотации ильменита не обеспечивается полнота отделения титановых минералов от примесей. Для устранения этого недостатка флотацию необходимо проводить с помощью вспомогательных веществ (добавок).

\section{Влияние добавок на эффективность отделения титана}

Вспомогательные вещества (добавки) - это вещества, повышающие эффективность процесса. В процессе флотации вспомогательные вещества будут способствовать эффективному отделению тяжелых минералов от песков, одновременно увеличивая степень обогащения тяжелых минералов. Например, таким способом можно отделить тяжелые минералы (рутил, ильменит и циркон) от пустой породы (квар- 
цевых песков) и отделить ильменит от рутила и цир- $\quad$ кона.
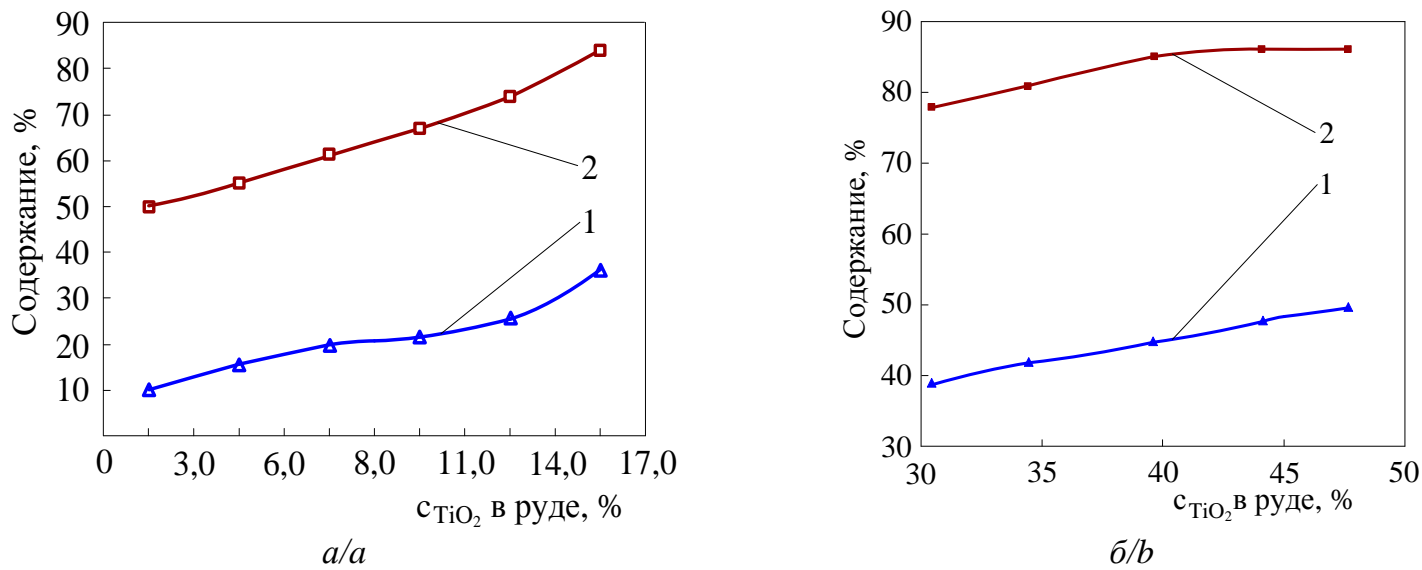

$\sigma / b$

Pис. 9. Влияние концентрации $\mathrm{TiO}_{2}$ в ильменитовой руде и пенной фракиии на эффективность флотации (а), степень обогащеени и конщентрацию титана в пенной фракцฺии (б): 1 - концентрация $\mathrm{TiO}_{2}$ в пенной фракции; 2 - степень обогащения титана

Fig. 9. Influence of $\mathrm{TiO}_{2}$ concentration in ilmenite ore and foam fraction on flotation efficiency $(a)$, beneficiation degree and titanium concentration in foam fraction $(b): 1-\mathrm{TiO}_{2}$ concentration in the foam fraction; 2 - beneficiation degree of titanium

В качестве добавок применяют:

- ингибитор кварцевых песков - силикат натрия $\left(\mathrm{Na}_{2} \mathrm{SiO}_{3}\right)$, способствующий отделению кварца и циркона от титансодержащих минералов;

- анионный ингибитор - фторид натрия NaF, способствующий образованию анионных комплексов и подавляющий флотацию легких компонентов в рудной смеси;

- катионный вспомогательный компонент - ацетат свинца $\left(\mathrm{Pb}\left(\mathrm{CH}_{3} \mathrm{COO}\right)_{2}\right)$, улучшающий флотационные свойства тяжелых минералов в смеси.

\section{Влияние силиката натрия на эффективность флотации}

В процессах обогащения для подавления флотируемости кварцевых песков и увеличения флотационных свойств титановых руд в качестве ингибитора используют кремнефторид натрия $\mathrm{Na}_{2} \mathrm{SiF}_{6}$. Недостаток его применения - сильная коррозия флотационного оборудования во фторидных средах. Изучим возможности использования силиката натрия $\left(\mathrm{Na}_{2} \mathrm{SiO}_{3}\right)$ в качестве ингибитора кварцевых песков. Исследования проведены в

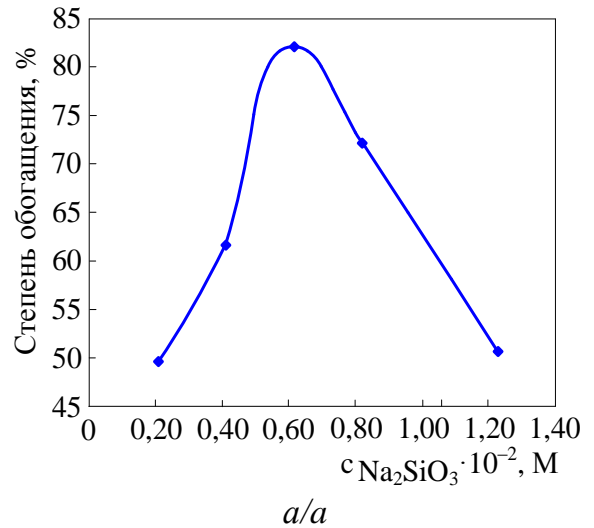

диапазоне концентраций $\mathrm{Na}_{2} \mathrm{SiO}_{3}$ от 0,083 до 0,5 г/л. На рис. 10, а показаны результаты влияния $\mathrm{Na}_{2} \mathrm{SiO}_{3}$ на флотационные свойства ильменитовой руды.

Показано, что с увеличением концентрации $\mathrm{Na}_{2} \mathrm{SiO}_{3}$ от 0,083 до 0,25 г/л эффективность флотации возрастает, концентрация Ті и степень обогащения постепенно увеличиваются. Однако при дальнейшем увеличении концентрации $\mathrm{Na}_{2} \mathrm{SiO}_{3}$ до 0,5 г/л эффективность процесса постепенно падает. Следовательно, оптимальная концентрация $\mathrm{Na}_{2} \mathrm{SiO}_{3}$ при флотации ильменитовой руды не превышает 0,25 г/л.

При проведении исследований по влиянию кислотности среды на степень обогащения ильменита с добавкой 0,25 г/л $\mathrm{Na}_{2} \mathrm{SiO}_{3}$ показано, что ее величина достигает $80 \%$ в диапазоне $\mathrm{pH}=4-7$ (рис. 10, б). Таким образом, в присутствии $\mathrm{Na}_{2} \mathrm{SiO}_{3}$ не только значительно снижаются флотационные свойства кварцевых песков, но и возрастает степень обогащения ильменита. Это также важно при отделении рутила от ильменита, когда значение $\mathrm{pH}$ изменяется с нейтрального $(\mathrm{pH}=7)$ до слабокислого $(\mathrm{pH}=4)$.

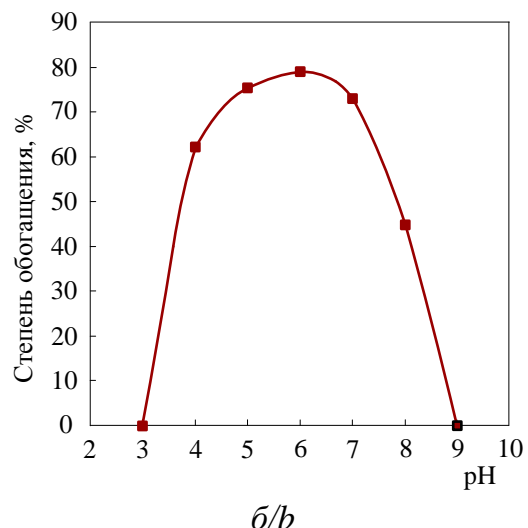

Рис. 10. Влияние концентрации силиката натрия (а) и рH среды при концентрации $\mathrm{Na}_{2} \mathrm{SiO}_{3}$ 0,25 г/л (б) на эффективность обогащения ильменита: Состав водной фазы - ильменит-NaOl-Na $\mathrm{SiO}_{3}$ 
Fig. 10. Influence of sodium silicate concentration (a) and the medium $\mathrm{pH}$ at $\mathrm{Na}_{2} \mathrm{SiO}_{3}$ concentration of $0,25 \mathrm{~g} / \mathrm{l}(\mathrm{b})$ on the efficiency of ilmenite benefication: composition of the aqueous phase - ilmenite- $\mathrm{NaOl}-\mathrm{Na}_{2} \mathrm{SiO}_{3}$

Влияние ацетата свинца

на степень обогащения ильменита

Обычно флотационные свойства тяжелых минералов, входящих в состав ильменита, изучают в присутствии $\mathrm{Pb}\left(\mathrm{NO}_{3}\right)_{2}$ [25]. Однако при гидролизе этой соли образуется азотная кислота, которая понижает $\mathrm{pH}$ среды. Это отрицательно влияет на процесс флотации и приводит к увеличению добавляемого в раствор количества $\mathrm{NaOl}$. Поэтому при проведении исследований по изучению влияния добавок $\mathrm{Pb}^{2+}$ на флотационные свойства ильменита использовали ацетат свинца $\mathrm{Pb}\left(\mathrm{CH}_{3} \mathrm{COO}\right)_{2}$. При его добавлении величина $\mathrm{pH}$ раствора практически не изменяется. Показано, что при концентрации $\mathrm{Pb}\left(\mathrm{CH}_{3} \mathrm{COO}\right)_{2}$, равной $8 \cdot 10^{-4} \mathrm{M}$, степень обогащения ильменита составляет $\sim 80 \%$ и при дальнейшем увеличении его концентрации практически не изменяется (рис. 11, $a$ ).

В диапазоне $\mathrm{pH}=4-12$ исследовано влияние кислотности среды на степень обогащения ильменита с добавкой $\mathrm{Pb}\left(\mathrm{CH}_{3} \mathrm{COO}\right)_{2}$. Показано, что наибольшая эффективность флотации достигается в диапазоне $\mathrm{pH}=6-8$ при степени обогащения более 80 \% (рис. 11, б) Минимальная концентрация $\mathrm{Pb}\left(\mathrm{CH}_{3} \mathrm{COO}\right)_{2}$, необходимая для проведения процесса, составляет $\sim 8 \cdot 10^{-4} \mathrm{M}$. Таким образом, $\mathrm{Pb}\left(\mathrm{CH}_{3} \mathrm{COO}\right)_{2}$ улучшает флотацион-

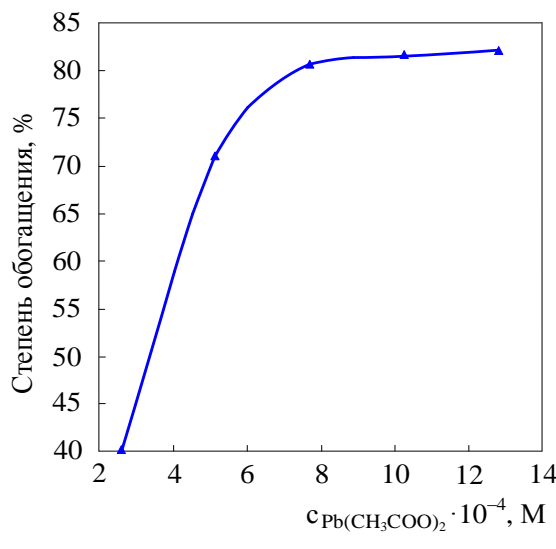

$a / a$ ные свойства ильменитовой руды, поэтому может использоваться в качестве добавки (активатора), улучшающей показатели процесса.

Кроме того, в кислой среде, при $\mathrm{pH}=4,5-6,5$ (рис. 12, a), при использовании фторида натрия обеспечивается максимальная эффективность флотации по сравнению с другими веществами. В этих условиях степень обогащения ильменита превышает $80 \%$, а при $\mathrm{pH}=5-6$ достигает $\sim 85 \%$ (рис. 12, б). Следовательно, при использовании $\mathrm{NaF}$ в качестве ингибитора анионов степень обогащения ильменита стремится к максимальным значениям. При концентрации фторида натрия, равной $1 \cdot 10^{-2} \mathrm{M}$, возрастает степень обогащения и улучшается эффективность флотации.

Изменение степени обогащения ильменита в зависимости от $\mathrm{pH}$ среды при использовании в качестве ингибиторов и вспомогательных компонентов $\mathrm{Na}_{2} \mathrm{SiO}_{3}, \mathrm{~Pb}\left(\mathrm{CH}_{3} \mathrm{COO}\right)_{2}$ и $\mathrm{NaF}$ в процессе флотации ильменита представлено на рис. 13. Показано, что наиболее высокая степень обогащения ильменитовой руды достигается при концентрациях 0,025 г/л $\mathrm{NaOl}$, 0,25 г/л $\mathrm{Na}_{2} \mathrm{SiO}_{3}, 8 \cdot 10^{-4} \mathrm{M} \mathrm{Pb}\left(\mathrm{CH}_{3} \mathrm{COO}\right)_{2}, 1 \cdot 10^{-2} \mathrm{M} \mathrm{NaF}-$ в диапазонах $\mathrm{pH}=5-7, \mathrm{pH}=4-7, \mathrm{pH}=6-8$ и $\mathrm{pH}=4,5-6,5$ соответственно.

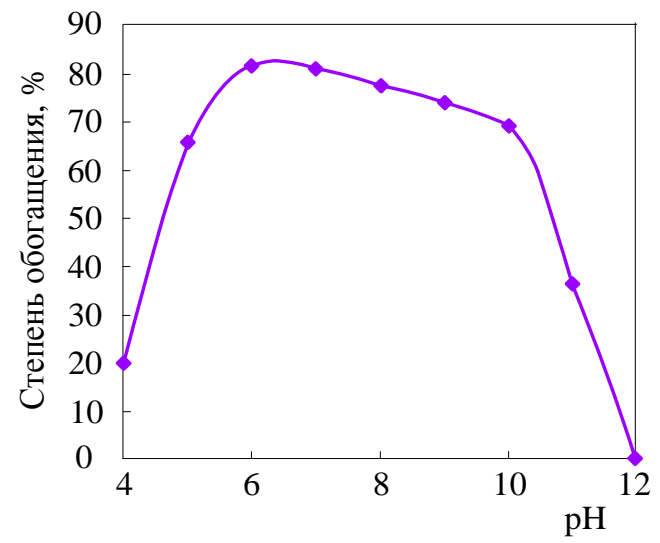

$\sigma / b$

Pис. 11. Зависимость изменения степени обогащения ильменита от конщентрации $\mathrm{Pb}\left(\mathrm{CH}_{3} \mathrm{COO}\right)_{2}(a)$ и от $\mathrm{pH}$ среды (б) (при концентрации $\mathrm{Pb}\left(\mathrm{CH}_{3} \mathrm{COO}\right)_{2} 8 \cdot 10^{-4} \mathrm{M}$

Fig. 11. Dependence of the change in ilmenite benefication degree on $\mathrm{Pb}\left(\mathrm{CH}_{3} \mathrm{COO}\right)_{2}$ concentration (a) and on the medium $\mathrm{pH}(\mathrm{b})$ (at the concentration of $\mathrm{Pb}\left(\mathrm{CH}_{3} \mathrm{COO}\right)_{2}-8 \cdot 10^{-4} \mathrm{M}$ )
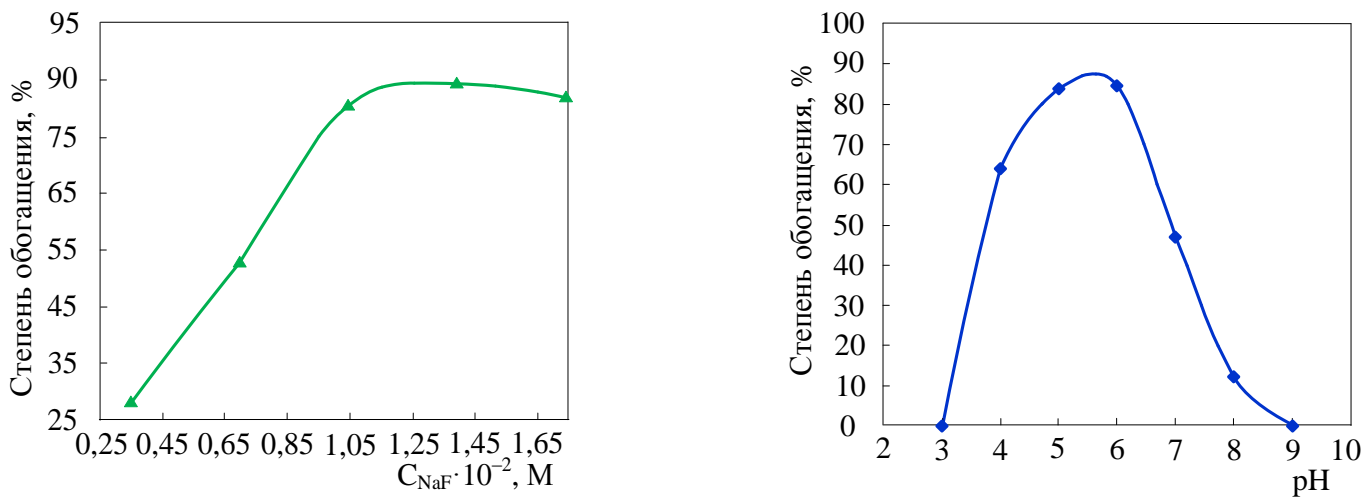
Puс. 12. Влияние NaF (a) и рН среды (б) при концентрации NaF $1 \cdot 10^{-2}$ М на флотационные свойства ильменита Fig. 12. Influence of $\mathrm{NaF}(a)$ and medium $\mathrm{pH}(\mathrm{b})$ at the $\mathrm{NaF}$ concentration of $1 \cdot 10^{-2} \mathrm{M}$ on ilmenite flotation properties

\section{Электролиз тетрафторида титана} в расплаве фторидных солей

Для выбора состава солевого расплава изучены температуры плавления различных смесей солей фторидов и хлоридов щелочных и щелочноземельных металлов. Показано, что наименьшей температурой плавления, равной $454{ }^{\circ} \mathrm{C}$, обладает эвтектика, имеющая состав $\operatorname{LiF}(0,465 \mathrm{M})-\mathrm{NaF}(0,115 \mathrm{M})-\mathrm{KF}(0,42 \mathrm{M})$ [26]. При добавлении в эту эвтектику $0,03 \mathrm{M} \mathrm{TiF}_{4}$ ee температура возрастает до $510{ }^{\circ} \mathrm{C}$. Для проведения электролиза и удержания фторидного расплава в жидком состоянии необходим перегрев на $40-50{ }^{\circ} \mathrm{C}$, поэтому процесс необходимо проводить при $550-560{ }^{\circ} \mathrm{C}$. Образующийся расплав обладает рядом преимуществ. Потенциал разложения $\mathrm{KF}\left(\mathrm{E}^{\circ}=-2,925 \mathrm{~B}\right)$ выше по сравнению с $\mathrm{NaF}\left(\mathrm{E}^{\circ}=-2,713 \mathrm{~B}\right)$ и $\mathrm{LiF}\left(\mathrm{E}^{\circ}=-2,495 \mathrm{~B}\right)$. Аналогичное значение для $\mathrm{TiF}_{4}\left(\mathrm{E}^{\circ}=-1,683 \mathrm{~B}\right)$, поэтому довольно легко провести процесс электролитического восстановления титанового порошка в эвтектической смеси фторидов щелочных металлов.

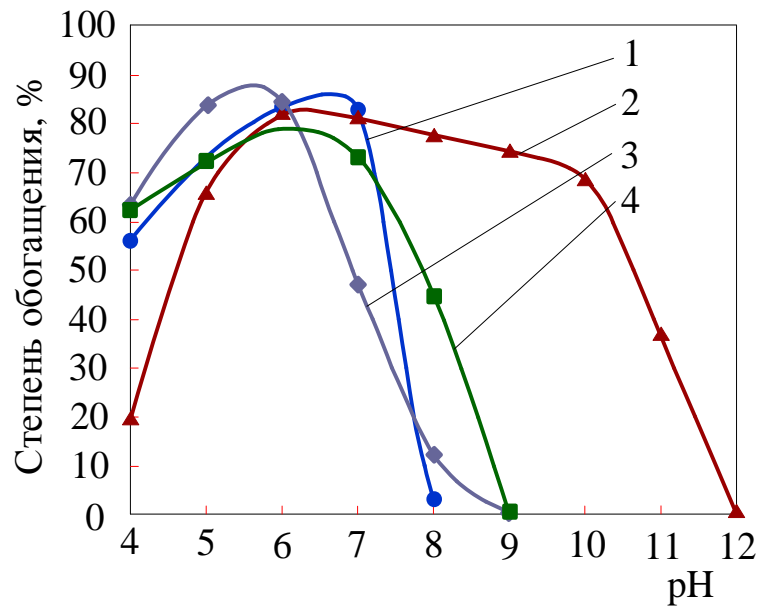

Рис. 13. Сравнение эффективности использования различных добавок в прочессе флотационного обогащения ильменитовой руды: 1 - ильменит с $\mathrm{NaOl} ; 2$ - ильменит $\mathrm{c}$ NaOl $и$ и $8 \cdot 10^{-4} \mathrm{M}$ $\mathrm{Pb}\left(\mathrm{CH}_{3} \mathrm{COO}\right)_{2} ; 3$ - ильменит с $\mathrm{NaOl}$ и $1 \cdot 10^{-2} \mathrm{M}$ $\mathrm{NaF} ; 4$-ильменит с NaOl и 0,25 г/л $\mathrm{Na}_{2} \mathrm{SiO}_{3}$

Fig. 13. Comparison of the efficiency of using various additives in the flotation concentration of ilmenite ore: 1 - ilmenite with $\mathrm{NaOl} ; 2$ - ilmenite with $\mathrm{NaOl}$ and $8 \cdot 10^{-4} \mathrm{M} \mathrm{Pb}\left(\mathrm{CH}_{3} \mathrm{COO}\right)_{2} ; 3$ - ilmenite with $\mathrm{NaOl}$ and $1 \cdot 10^{-2} \mathrm{M} \mathrm{NaF} ; 4$ - ilmenite with $\mathrm{NaOl}$ and

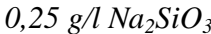

Для выделения титанового порошка из катодного осадка необходим реагент, в котором компоненты солевого расплава $\left(\mathrm{LiF}, \mathrm{NaF}, \mathrm{KF}\right.$ и $\left.\mathrm{K}_{2} \mathrm{TiF}_{6}\right)$ хорошо растворяются, а Ті-порошок остается в твердом состоянии. Такими свойствами обладает безводный HF, поэтому при взаимодействии осадка с HF Тi-порошок отделяется от солей электролита. При электролизе на аноде образуется фтор, но из-за высокой температуры электролита анодный эффект происходит очень редко. KF медленно накапливается в расплаве, поскольку его большая часть выносится с катодным продуктом. $\mathrm{NaF}$ и $\mathrm{LiF}$ в электролите не влияют на электролиз, даже если их содержание в электролите достигает $50 \%$.

Для запуска электролизера его внутренний объем дегазировали, откачивая воздух и создавая в нем давление не более 100 мм рт.ст. Для удаления фторсодержащих газов электролит нагревали до 1000$1300{ }^{\circ} \mathrm{C}$. Затем электролизер заполняли предварительно очищенным аргоном. После этого в электролизере в токе Ar наплавляли фториды лития, натрия, калия и $\mathrm{K}_{2} \mathrm{TiF}_{6}$. Для очистки электролита от солей элементов, обладающих высокой плотностью, и воды при разности потенциалов $1,3-1,8$ В и нагревании до $550{ }^{\circ} \mathrm{C}$ получали очищенный от примесей электролит. Увеличив силу тока I до 100-200 А, катодную плотности тока до $\mathrm{D}_{\mathrm{K}}=2,7-3,0 \mathrm{~A} / \mathrm{cm}^{2}$ и напряжение до 4,44,9 В, осаждали титановый порошок на никелевом катоде. При этом масса выделившегося титана приближалась к 60 \% от теоретически возможной, а степень извлечения - к 84-87 \%. Скорость выделения продукта электролиза на катоде составила 0,5 г/А-час. Одновременно на графитовом аноде происходило выделение фтора.

При электролизе $\mathrm{K}_{2} \mathrm{TiF}_{6}$ катодную плотность тока можно изменять в диапазоне от 0,003 до $1,50 \mathrm{~A} / \mathrm{cm}^{2}$. При ее величине $0,05 \mathrm{~A} / \mathrm{cm}^{2}$ и ниже частицы образующегося осадка имеют пластинчатую форму, а при дальнейшем возрастании катодной плотности тока $\left(\mathrm{D}_{\mathrm{K}}\right)$ на катоде образуются частицы дендритной формы. При увеличении $\mathrm{D}_{\mathrm{K}}$ до $6,5 \mathrm{~A} / \mathrm{cm}^{2}$ на катоде образуется порошок, имеющий аморфную структуру, который при незначительных механических сотрясениях сползает с катода в электролит. Выделить титан, имеющий аморфную структуру, из электролита довольно трудно. В связи с тем, что полученный порошок обладает высокой окисляемостью на воздухе, в дальнейшем перевести титан в слиток практически невозможно.

При уменьшении концентрации $\mathrm{TiF}_{4}$ (менее $0,01 \mathrm{M}$ ) в расплаве фторидного электролита на границе радела катод-расплав появлялись вспышки, поэтому необходимо постоянно пополнять электролит тетрафторидом титана. Для выделения титанового порошка из образовавшегося осадка необходимо сначала удалить катод из расплава, а затем охладить в среде аргона. При этом электролит в электролизере также переходил в твердое состояние. В полученном таким образом осадке содержалось до $33 \%$ титана, остальное фторидные соли электролита. Полученный материал измельчали, промывали уайт спиритом, из образовавшейся пульпы выделяли твердую фазу, которую высушивали ацетоном или этанолом. В табл. 2 показан химический и гранулометрический анализы тита- 
нового порошка, полученного электролизом предварительно очищенного $\mathrm{K}_{2} \mathrm{TiF}_{6}$ и технической чистоты. Изменение выхода по току и по титану от начальной концентрации $\mathrm{K}_{2} \mathrm{TiF}_{6}$ и температуры приведены на рис. 14.

Таблица 2. Химический и гранулометрический составы титанового порошка, полученного электролизом смеси $\mathrm{LiCl}-\mathrm{KCl}-\mathrm{NaCl}-\mathrm{K}_{2} \mathrm{TiF}_{6}$

Table 2. Chemical and granulometric compositions of titanium powder obtained by electrolysis of a mixture of LiCl-KCl$\mathrm{NaCl}-\mathrm{K}_{2} \mathrm{TiF}_{6}$

\begin{tabular}{|c|c|c|c|c|c|c|c|c|c|c|c|}
\hline $\begin{array}{c}\text { Исходное соединение } \\
\text { Initial material }\end{array}$ & \multicolumn{6}{|c|}{$\begin{array}{l}\text { Крупность класса, мм } \\
\text { Class size, mm }\end{array}$} & \multicolumn{4}{|c|}{$\begin{array}{l}\text { Химический состав } \\
\text { Chemical composition }\end{array}$} & \multirow{2}{*}{ 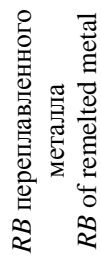 } \\
\hline $\begin{array}{l}\text { Неочищенный } \mathrm{K}_{2} \mathrm{TiF}_{6} \\
\text { Raw } \mathrm{K}_{2} \mathrm{TiF}_{6}\end{array}$ & 0,51 & 0,154 & 0,112 & 0,075 & 0,048 & $-0,048$ & $\mathrm{Zr}$ & $\mathrm{C}$ & $\mathrm{N}$ & $\mathrm{O}$ & \\
\hline $\begin{array}{l}\text { Технической чистоты } \\
\text { Technical purity }\end{array}$ & 2,8 & 31 & 22 & 15,8 & 18 & 15,4 & 99,3 & 0,047 & 0,011 & 0,041 & 85 \\
\hline $\begin{array}{l}\text { Предварительно очищенный } \\
\text { Pre-cleaned material }\end{array}$ & 13,7 & $30-50$ & $15-18$ & $7,6-12,7$ & $8,4-19,8$ & $5,2-17,6$ & 99,8 & 0,03 & 0,002 & $0,05-0,07$ & $84-85$ \\
\hline
\end{tabular}

В диапазоне концентраций $10-36 \% \mathrm{~K}_{2} \mathrm{TiF}_{6}$ при $500-550{ }^{\circ} \mathrm{C}$ и катодной плотности тока $\mathrm{D}_{\mathrm{K}}=4,0 \mathrm{~A} / \mathrm{cm}^{2}$ выполнены исследования по изучению влияния концентрации $\mathrm{K}_{2} \mathrm{TiF}_{6}$ в расплаве. Максимальный выход по току получен при содержании в расплаве 25-30 \% $\mathrm{K}_{2} \mathrm{TiF}_{6}$. Оптимальная температура электролиза равна $520-540{ }^{\circ} \mathrm{C}$. При проведении исследований с изменением начальной $\mathrm{D}_{\mathrm{K}}$ от 0,9 до $6,8 \mathrm{~A} / \mathrm{cm}^{2}$ сделан вывод о том, что наилучшие результаты получаются при 3,5-4,0 A/cм². Степень выделения титана по силе тока составила 60-65\%, по массе полученного титанового порошка - 50-60\%. В образовавшемся катодном осадке находилось не менее $30 \%$ металлического титана.

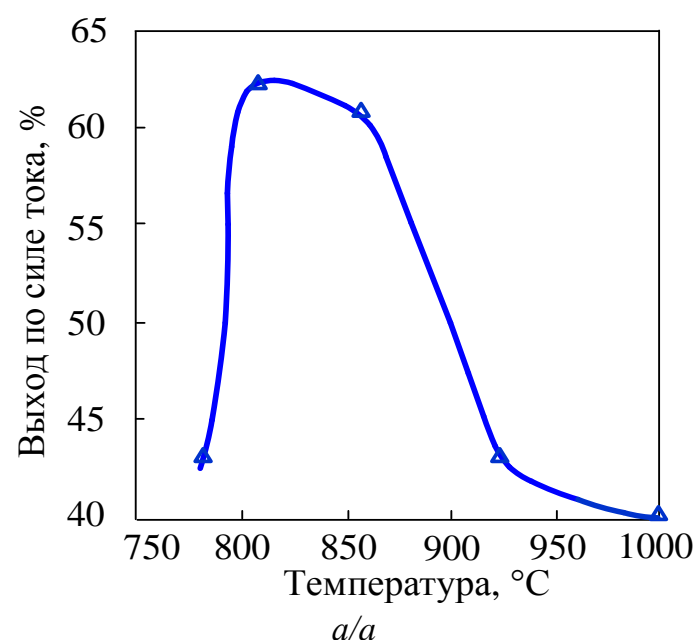

Рис. 14. Зависимость изменения выхода по току и металлу от температуры (а) и начальной концентрации $K_{2} T i F_{6}$ (б): 1 - выход по титану; 2 - выход по току

Fig. 14. Dependence of current and metal efficiency on temperature (a) and initial concentration of $K_{2} T i F_{6}(b): 1-$ titanium recovery rate; 2 - current utilization rate

Таблица 3. Гранулометрический состав отмытого титанового порошка

Table 3. Granulometric composition of the washed titanium powder

\begin{tabular}{|c|c|c|c|c|c|c|}
\hline $\begin{array}{c}\text { Размер частиц, мм } \\
\text { Рarticle size, mm }\end{array}$ & $+0,275$ & $-0,275$ & $-0,157$ & $-0,108$ & $-0,072$ & $-0,058$ \\
\hline Содержание/Content, \% & $5-11$ & $7-9$ & $14-21$ & $9-12$ & $16-21$ & $31-39$ \\
\hline
\end{tabular}


После получения титанового слитка методом электронно-лучевой плавки твердость компактного титана составила $\mathrm{HB}=165-175$ МПа и он обладал высокой пластичностью. Из него и титановых сплавов были изготовлены различные изделия, например кольца, толщина стенок которых не превышала 0,4 мм.

Таблица 4. Концентращия примесей в полученном порошке электролитического титана

Table 4. Content of impurities in the washed powder of electrolytic titanium

\begin{tabular}{|c|c|c|c|c|c|}
\hline \multirow{2}{*}{ 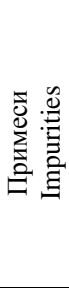 } & \multicolumn{2}{|c|}{$\begin{array}{c}\text { Концентрация } \\
\text { примесей, \% } \\
\text { Impurity } \\
\text { concentration, \% }\end{array}$} & \multirow{2}{*}{ 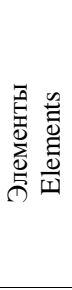 } & \multicolumn{2}{|c|}{$\begin{array}{c}\text { Концентрация } \\
\text { примесей, \% } \\
\text { Impurity } \\
\text { concentration, \% }\end{array}$} \\
\hline & $\begin{array}{c}\text { в титановом } \\
\text { порошке } \\
\text { in titanium } \\
\text { powder }\end{array}$ & $\begin{array}{l}\text { в исход- } \\
\text { ном } \\
\mathrm{K}_{2} \mathrm{TiF}_{6} \\
\text { in raw } \\
\mathrm{K}_{2} \mathrm{TiF}_{6}\end{array}$ & & $\begin{array}{l}\text { в титановом } \\
\text { порошке } \\
\text { in titanium } \\
\text { powder }\end{array}$ & $\begin{array}{l}\text { в исход- } \\
\text { ном } \\
\mathrm{K}_{2} \mathrm{TiF}_{6} \\
\text { in raw } \\
\mathrm{K}_{2} \mathrm{TiF}_{6}\end{array}$ \\
\hline $\mathrm{O}$ & 0,06 & - & $\mathrm{Si}$ & 0,04 & 0,09 \\
\hline $\mathrm{N}$ & 0,002 & - & $\mathrm{Cr}$ & $<0,004$ & 0,04 \\
\hline $\mathrm{C}$ & $<0,04$ & - & Co & 0,04 & 0,09 \\
\hline $\mathrm{Fe}$ & 0,013 & 0,035 & $\mathrm{Mg}$ & $<0,01$ & - \\
\hline $\mathrm{Ni}$ & 0,007 & $<0,005$ & Mo & $<0,01$ & - \\
\hline $\mathrm{Cu}$ & $<0,0009$ & 0,0009 & $\mathrm{Ce}$ & 0,0019 & - \\
\hline $\mathrm{Ti}$ & 0,0019 & 0,009 & B & 0,9 г/Т & - \\
\hline $\mathrm{Mn}$ & 0,0018 & $<0,00182$ & W & $<0,009$ & - \\
\hline
\end{tabular}

\section{Заключение}

При проведении исследований по обогащению ильменитовых руд и химической переработке полученных концентратов месторождения Ха Тинь (Вьетнам) показано, что:

- в процессе электростатической сепарации при увеличении напряжения между электродами сепаратора до 30 кВ тяжелые титановые компоненты, концентрирующиеся в 1-6 ячейках, можно отделить от пустой породы, собирающейся в 8-10 ячейках сепаратора;

- во флотационном процессе при использовании в качестве собирателя (коллектора) олеата натрия $(\mathrm{NaOl})$ диапазон изменения $\mathrm{pH}$ среды составляет $5-7$;

\section{СПИСОК ЛИТЕРАТУРЫ}

1. Kroll W.J. Ductile titanium // Trans. Electrochem. Soc. - 1940. V. 112 . - P. 35-47.

2. Reactive jet and cyclonic attrition analysis of ilmenite in chemical looping combustion systems / T. Nelson, J.G. Watt, D. Laudal, H. Feilen, M. Mann, S. Srinivasacharb // International Journal of Greenhouse Gas Control. - 2019. - V. 91. - Article number 102837.

3. Rejith R.G., Sundararajan M. Combined magnetic, electrostatic, and gravity separation techniques for recovering strategic heavy minerals from beach sands // Marine Georesources \& Geotechnology. - 2018. - V. 36. - № 8. - P. 959-965.

4. Preconcentration of ultrafine ilmenite ore using a superconducting magnetic separator / S. Shen, Z. Yuan, J. Liu, Q. Meng, H. Hao /l Powder Technology. - 2020. - V. 360. - P. 1-9.

5. Эдильбаев А.И. Технология сухого обогашения ильменитовых руд Сатпаевского месторождения // Горный журнал. 2009. - № 6. - C. 70-71.

6. Обогащение чернового титаномагнетитового концентрата методом мокрой магнитной сепарации / А.С. Атмаджиди,
- с увеличением $\mathrm{pH}$ среды возрастает концентрация $\mathrm{NaOl}$; при рН среды меньше 2 флотация невозможна, поскольку не происходит образования пены; продолжительность проведения процесса изменяется в пределах 5-10 мин; оптимальное время - 8 мин;

- при использовании в качестве ингибитора $\mathrm{Na}_{2} \mathrm{SiO}_{3}$ эффективность флотации снижается, но концентрация титана в пенной фракции возрастает, поэтому $\mathrm{Na}_{2} \mathrm{SiO}_{3}$ можно использовать для увеличения концентрации целевых компонентов в обогащенной фракции;

- в процессе обогащения ильменита в присутствии $\sim 8 \cdot 10^{-4} \mathrm{M} \mathrm{Pb}\left(\mathrm{CH}_{3} \mathrm{COO}\right)_{2}$ увеличивается диапазон оптимальных значений рН среды $(\mathrm{pH}=5-10)$, однако при этом степень обогащения снижается с $\sim 85$ до $\sim 82 \%$;

- среди исследованных ингибиторов и добавок специфическими свойствами обладает фторид натрия; в среде $1 \cdot 10^{-2} \mathrm{M} \mathrm{NaF}$ степень обогащения ильменита возрастает до 85 \%. В то же время диапазон оптимальных значений $\mathrm{pH}$ среды уменьшается и смещается в кислую среду $(\mathrm{pH}=4-6)$;

- в ходе электролитического синтеза титанового порошка подтвержден состав солевых компонентов щелочных металлов $(0,465 \mathrm{M} \mathrm{LiF}-0,115 \mathrm{M}$ $\mathrm{NaF}-0,42 \mathrm{M} \mathrm{KF}$ ), обладающих минимальной температурой плавления, равной $454{ }^{\circ} \mathrm{C}$;

- при добавлении в указанную эвтектику 0,03 М $\mathrm{TiF}_{4}$ еe температура возрастает на $40-50{ }^{\circ} \mathrm{C}$, но при $550-560{ }^{\circ} \mathrm{C}$ возможно осуществить процесс электролиза с выходом по току $~ 60 \%$, степенью выделения титана - 84-87 \% и скоростью его катодного осаждения не менее 0,5 г/А-час;

- в процессе электролиза образуется титановый порошок, химический и гранулометрический составы которого, а также твердость, отвечают требованиям к материалу для изготовления изделий из компактного титана и его сплавов.

Представленные в статье исследования поддержаны СЕ Программой Томского политехнического Университета и Вьетнамского института по Атомной энергии.

К.В. Гончаров, Т.В. Олюнина, Г.Б. Садыхов // Цветные металлы. - 2018. - № 9. - С. 19-24.

7. Гришкин Н.Н. Исследование на обогатимость ильменитрутил-цирконовых песков Тарского месторождения с получением титансодержащих концентратов // Обогащение руд. 2005. - № 4. - C. 47-48.

8. Минеральный состав отходов обогащения титаномагнетитовых руд Кусинского месторождения (Южный Урал) / В.И. Попова, В.А. Попов, В.А. Муфтахов, В.А. Котляров // Минералогия. - 2016. - № 2. - С. 70-81.

9. Махоткина Е.С., Шубина М.В. Химическая переработка отходов обогащения титаномагнетитовых руд Кусинского месторождения // Актуальные проблемы современной науки, техники и образования. -2018 . - Т. 9. - № 2. - С. 71-73.

10. Шавакулева О.П. Разработка комбинированной технологии обогащения труднообогатимой титано магнетитовой руды Копанского месторождения: автореф. дис. ... канд. техн. наук. Магнитогорск, 2007. - 19 c.

11. Чижевский В.Б., Шавакулева О.П. Обогащение титаномагнетитовых руд с целью получения кондиционного ильменитово- 
го концентрата // Вестник МГТУ им. Г.И. Носова. - 2013. № 4. - C. 10-13.

12. Semi-continuous magnesium-thermal method for producing pure titanium: Patent 8007562 B2 USA. Fil. 08.16.2010; Publ 04.30.2011.

13. Doblin C., Chryss A., Monch A. Titanium powder from the TiRO ${ }^{\mathrm{TM}}$ process // Key Engineering Materials. - 2012. - V. 520. P. $95-100$.

14. Hansen D.A., Gerdemann S.J. Producing titanium powder by continuous vapor-phase reduction // JOM. - 1998. - V. 50. № 11. - P. 56-58.

15. Van Vuuren D.S., Oosthuizen S.J., Heydenrych M.D. Titanium production via metallothermic reduction of $\mathrm{TiCl} 4$ in molten salt: Problems and products // Journal of the Southern African Institute of Mining and Metallurgy. - 2011. - V. 111. - № 3. - P. 141-147.

16. Froes F.H. Titanium and other light metals: let's do something about cost // JOM. - 1998. - V. 50. - № 9. - P. 15.

17. Chen G.Z., Fray D.J., Farthing T.W. Direct electrochemical reduction of titanium dioxide to titanium in molten calcium chloride // Nature. - 2000. - V. 407. - P. 361-364.

18. Okabe T.H., Oda T., Mitsuda Y. Titanium powder production by preform reduction process (PRP) // Journal of Alloys and Compounds. - 2004. - V. 364. - № 1-2. - P. 156-163.

19. Jiao S.Q., Zhu H.M. Electrolysis of Ti2CO solid solution prepared by $\mathrm{TiC}$ and $\mathrm{TiO} 2$ // Journal of Alloys and Compounds. - 2007. V. 438. - P. 243-246.

20. Suzuki R.O., Ono K. Direct reduction processes for titanium oxide in molten salt // Journal of the Minerals, Metals and Materials Society. - 2007. - V. 59. - № 1. - P. 68-71

21. Titanium metal production via oxycarbide electrorefining D. Jewell, S.Q. Jiao, M. Kurtanjek, D.J. Fray. International Titanium Association, 2012. URL: https://cdn.ymaws.com/titanium.
org/resource/resmgr/2010_2014_papers/JewellDaniel_2012.pdf (дата обращения 15.12.2021)

22. Применение процесса флотации для обогашения ильменитовых руд из Вьетнама / Ш.Х. Ле, Т.Б. Киеу, В.А. Карелин, И.И. Жерин, Н.В. Карелина, А.А. Смороков // Бутлеровские сообщения. - 2021. - Т. 67. - № 8. - С. 1-9.

23. Thermodynamics and kinetics research of the fluorination process of the concentrate rutile / V.A. Karelin, Son Hai Le, N.V. Karelina, A.N. Strashko, A.V. Sazonov, H.M.T. Le // Metals. - 2022. V. 12. - Iss. 1. - Article Number 34.

24. Fluorination of rutile, electrochemical reduction of titanium fluoride to titanium, and its separation from the electrolyte salts melt / V.A. Karelin, F.A. Voroshilov, A.N. Strashko, A.V. Sazonov, N.V. Karelina // Journal of Chemical Technology and Metallurgy. - 2020. - V. 55. - Iss. 5. - P. 1111-1118.

25. Bulatovic S.M. Handbook of flotation reagents: chemistry, theory and practice. V. 2: Flotation of gold, PGM and oxide minerals // 25. Flotation of Titanium Minerals. - P. 180. - September 1, 1991. URL:

https://mycourses.aalto.fi/pluginfile.php/910106/mod_resource/co ntent/1/25---Flotation-of-Titanium_2010_Handbook-of-FlotationReagents--Chemistry--T.pdf (дата обращения 15.09.2021).

26. Сухотин А.М. Справочник по электрохимии. - Л.: Химия, 1981. $-488 \mathrm{c}$

27. Titanium powder segregation out of cathode deposit of titanium electrolyzers / V.A. Karelin, A.N. Strashko, V.I. Sobolev, A.V. Sazonov, N.V. Karelina // Journal of Chemical Technology and Metallurgy. - 2018. - V. 53. - Iss. 5. - P. 856-863.

Поступила 10.01.2022 2.

\section{Информация об авторах}

Карелин В.A., доктор технических наук, профессор отделения ядерного топливного цикла Инженерной ядерно-технологической школы Национального исследовательского Томского политехнического университета.

Ле Хай Шон, начальник лаборатории Института технологии радиоактивных и редкоземельных элементов Вьетнамского института по Атомной энергии.

Карелина Н.B., аспирант отделения ядерного топливного цикла Инженерной ядерно-технологической школы Национального исследовательского Томского политехнического университета.

Ле Хуонг Тхи Май, доктор технических наук, профессор Высшего университета науки и технологий Вьетнамской академии науки и технологий. 


\title{
PROCESSES OF ELECTROSTATIC SEPARATION AND FLOTATION IN THE BENEFICIATION OF ILMENITE ORES FROM VIETNAM AND CHEMICAL PROCESSING OF THE OBTAINED CONCENTRATES
}

\author{
Vladimir A. Karelin ${ }^{1}$ \\ vakarelin@tpu.ru
}

Son H. Le'2, son.hut2006@gmail.com

Nadezhda V. Karelina', nvkarelina@yandex.ru

\section{Huong Le Thi Mai3,} huonghvc@gmail.com

${ }^{1}$ National Research Tomsk Polytechnic University, 30, Lenin avenue, Tomsk, 634050, Russia.

2 Institute for Technology of Radioactive and Rare Earth Elements, Vietnam Atomic Energy Institute, 48, Lang Ha, Dong Da, Hanoi, 11513, Vietnam.

3 Graduate University of Science and Technology, Vietnam academy of Science and Technology, Hoang Quoc Viet street, Cau Giay district, Vietnam.

The relevance of the study is determined by the creation of a fundamentally new method for the synthesis of titanium powders of high purity from ilmenite ores of Vietnam deposits, containing a mixture of ilmenite with rutile in the heavy fraction. This is one of the priority areas for the integrated development of deposits of rare and rare earth elements in Vietnam.

The main aim: selection of conditions, methods and sequence of technological operations for the beneficiation of Vietnamese ilmenite ores and their subsequent chemical processing to obtain high-purity titanium.

Objects: ilmenite ore of the Ha Tinh deposit (Vietnam) with a high content of oxides of titanium, iron, zirconium and a low content of silicon, aluminum, rare earth elements, vanadium, as well as ilmenite concentrate obtained as a result of enrichment of the original ilmenite ore.

Methods: in the beneficiation process - electrostatic separation, flotation, the use of collectors, activators and depressants added to flotation reagents; in the electrolytic synthesis of titanium - the use of a low-melting eutectic of fluoride salts of alkali metals with the addition of titanium tetrafluoride; selection of the conditions for starting the electrolyzer, cathode current density, current and voltage for the deposition of titanium on the cathode; investigation of the optimal conditions for the release of titanium powder at low temperatures using anhydrous hydrogen fluoride.

Results. The prospects of using the methods of electrostatic separation and flotation in the dressing of Vietnamese ilmenite ores of the Ha Tinh deposit are shown. An ilmenite concentrate with a titanium dioxide content of more than $50 \%$ was obtained. The advantages of using the method of direct fluorination of an ilmenite concentrate with gaseous fluorine are substantiated, which makes it possible to ensure both the completeness of the decomposition of the solid phase and to separate the fluorides of titanium, niobium, vanadium and silicon that pass into the gas phase from those remaining in the condensed state - fluorides of iron, zirconium, hafnium and cerium. This allows you to optimize the number of stages in the subsequent processing of titanium tetrafluoride and the synthesis of metallic titanium. In titanium electrolysis, the authors have substantiated the use of composition of the eutectic of fluoride salts of alkali metals LiF (0,465 M)-NaF $(0,115 \mathrm{M})$ $\mathrm{KF}(0,42 \mathrm{M})$, which has a minimum melting point $\left(454^{\circ} \mathrm{C}\right)$ and the range of changes in the concentration of $\mathrm{K}_{2} \mathrm{TiF}_{6}(25-30 \%)$. In this case, the values of current density and current efficiency approach the maximum values of 3,5-4,0 A/cm 2 and $60-65 \%$, respectively. The content of impurities in titanium powder does not exceed $0,135 \%$, which meets the requirements for the manufacture of products from compact titanium.

\section{Key words:}

IImenite ore and concentrate from Vietnam, beneficiation by electrostatic separation and flotation,

electrolysis in low-melting eutectic of alkali metal and titanium fluorides, granulometric and chemical compositions of titanium powder.

The research introduced in the paper are supported by the Strategic Development Program of the Tomsk Polytechnic University and Vietnam Atomic Energy Institute.

\section{REFERENCES}

1. Kroll W.J. Ductile titanium. Trans. Electrochem. Soc., 1940, vol. 112 , pp. $35-47$

2. Nelson T., Watt J.G., Laudal D., Feilen H., Mann M., Srinivasacharb S. Reactive jet and cyclonic attrition analysis of ilmenite in chemical looping combustion systems. International Journal of Greenhouse Gas Control, 2019, vol. 91, Article number 102837.
3. Rejith R.G., Sundararajan M. Combined magnetic, electrostatic, and gravity separation techniques for recovering strategic heavy minerals from beach sands. Marine Georesources \& Geotechnology, 2018, vol. 36, no. 8, pp. 959-965.

4. Shen S., Yuan Z., Liu J., Meng Q., Hao H. Preconcentration of ultrafine ilmenite ore using a superconducting magnetic separator. Powder Technology, 2020, vol. 360, pp. 1-9. 
5. Edilbaev A.I. Technology of ilmenite ores dry enrichment of the Satpaevsky deposit. Mining journal, 2009, no. 6, pp. 70-71. In Rus.

6. Atmadzhidi A.S., Goncharov K.V., Olyunina T.V., Sadyhov G.B. Beneficiation of crude titanomagnetite concentrate by wet magnetic separation. Non-ferrous metals, 2018, no. 9, pp. 19-24. In Rus.

7. Grishkin N.N. Washability analysis of the of ilmenite-rutile-zircon sands of the Tara deposit with the production of titaniumcontaining concentrates. Ore beneficiation, 2005, no. 4, pp. 47-48. In Rus.

8. Popova V.I., Popov V.A., Muftahov V.A., Kotlyarov V.A. Mineral composition of tailings of titanomagnetite ores beneficiation of the Kusinsky deposit (Southern Ural). Mineralogy, 2016, no. 2, pp. 70-81. In Rus.

9. Shubina M.V., Mahotkina E.S. Chemical processing of tailings of titanomagnetite ores of the Kusinskoye deposit. Actual problems of modern science, technology and education, 2018, vol. 9, no. 2, pp. 71-73. In Rus.

10. Shavakuleva O.P. Razrabotka kombinirovannoy tekhnologii obogashcheniya trudnoobogatimoy titano magnetitovoy rudy Kopanskogo mestorozhdeniya. Avtoreferat Dis. Kand. nauk [Development of a combined technology for enrichment of refractory titanium-magnetite ore of the Kopanskoye deposit. Cand. Diss. Abstract]. Magnitogorsk, 2007. 19 p.

11. Chizhevskiy V.B., Shavakuleva O.P. Beneficiation of titanomagnetite ores in order to obtain conditioned ilmenite concentrate. Bulletin of the Moscow State Technical University named after G.I. Nosov, 2013, no. 4, pp. 10-13.

12. Goldsteins L. Semi-continuous magnesium-thermal method for producing pure titanium. Patent 8007562 B2. USA, 2011.

13. Doblin C., Chryss A., Monch A. Titanium powder from the TiRO ${ }^{\mathrm{TM}}$ process. Key Engineering Materials, 2012, vol. 520, pp. 95-100.

14. Hansen D.A., Gerdemann S.J. Producing titanium powder by continuous vapor-phase reduction. JOM, 1998, vol. 50, pp. 56-58.

15. Van Vuuren D.S., Oosthuizen S.J., Heydenrych M.D. Titanium production via metallothermic reduction of $\mathrm{TiCl}_{4}$ in molten salt: Problems and products. Journal of the Southern African Institute of Mining and Metallurgy, 2011, vol. 111, no. 3, pp. 141-147.

16. Froes F.H. Titanium and other light metals: let's do something about cost. JOM, 1998, vol. 50, no. 9, pp. 15 .

17. Chen G.Z., Fray D.J., Farthing T.W. Direct electrochemical reduction of titanium dioxide to titanium in molten calcium chloride. Nature, 2000, vol. 407, pp. 361-364.
18. Okabe T.H., Oda T., Mitsuda Y. Titanium powder production by preform reduction process (PRP). Journal of Alloys and Compounds, 2004, vol. 364, no. 1-2, pp. 156-163.

19. Jiao S.Q., Zhu H.M. Electrolysis of $\mathrm{Ti}_{2} \mathrm{CO}$ solid solution prepared by $\mathrm{TiC}$ and $\mathrm{TiO}_{2}$. Journal of Alloys and Compounds, 2007, vol. 438, pp. 243-246.

20. Suzuki R.O., Ono K. Direct reduction processes for titanium oxide in molten salt. Journal of the Minerals, Metals and Materials Society, 2007, vol. 59, no. 1, pp. 68-71.

21. Jewell D., Jiao S.Q., Kurtanjek M., Fray D.J. Titanium metal production via oxycarbide electrorefining. International Titanium Association, 2012. Available at: https://cdn.ymaws.com/ titanium.org/resource/resmgr/2010_2014_papers/JewellDaniel_2012.pd $\mathrm{f}$ (accessed 15 December 2021)

22. Le Sh.H., Kieu T.B., Karelin V.A., Zherin I.I., Karelina N.V., Smorokov A.A. Application of flotation process for beneficiation of ilmenite ores from Vietnam. Butlerov messages, 2021, vol. 67, no. 8, pp.1-9.

23. Karelin V.A., Son Hai Le, Karelina N.V., Strashko A.N., Sazonov A.V., Le Huong M.T. Thermodynamics and kinetics research of the fluorination process of the concentrate rutile. Metals, 2022, vol. 12, Iss. 1, Article Number 34.

24. Karelin V.A., Voroshilov F.A., Strashko A.N., Sazonov A.V., Karelina N.V. Fluorination of rutile, electrochemical reduction of titanium fluoride to titanium, and its separation from the electrolyte salts melt. Journal of Chemical Technology and Metallurgy, 2020, vol. 55, Issue 5, pp. 1111-1118.

25. Bulatovic S.M. Handbook of flotation reagents: chemistry, theory and practice. Vol. 2: Flotation of gold, PGM and oxide minerals. 25. Flotation of Titanium Minerals. 180 p. September 1, 1991. (eBook ISBN: 9780080932095 Paperback ISBN: 9781493302413). Available at: https://mycourses.aalto.fi/ pluginfile.php/910106/mod_resource/content/1/25---Flotation-ofTitanium_2010_Handbook-of-Flotation-Reagents--ChemistryT.pdf (accessed 15 September 2021).

26. Suhotin A.M. Spravochnik po elektrohimii [Handbook of electrochemistry]. Leningrad, Khimiya Publ., 1981. 488 p.

27. Karelin V.A., Strashko A.N., Sobolev V.I., Sazonov A.V., Karelina N.V. Titanium powder segregation out of cathode deposit of titanium electrolyzers. Journal of Chemical Technology and Metallurgy, 2018, vol. 53, Iss. 5, pp. 856-863.

Received: 10 January 2022.

\section{Information about the authors}

Vladimir A. Karelin, Dr. Sc., professor, National Research Tomsk Polytechnic University.

Son H. Le, head of the laboratory, Institute for Technology of Radioactive and Rare Earth Elements, Vietnam Atomic Energy Institute.

Nadezhda V. Karelina, postgraduate student, National Research Tomsk Polytechnic University.

Huong Le Thi Mai, Dr. Sc., professor, Graduate University of Science and Technology, Vietnam academy of Science and Technology. 